\title{
As passagens de Tata Amaral: Entrevista com Tata Amaral ${ }^{1}$ Lúcia Nagib $^{2}$ e Samuel Paiva ${ }^{3}$
}

Tata Amaral é figura central da chamada Retomada do Cinema Brasileiro, iniciada em meados dos anos 1990. Seu filme Um Céu de Estrelas, de 1997, constituiu um marco do renascimento do cinema independente, além de lançar um estilo cinematográfico feminista sem paralelos no Brasil. A este seguiram-se dois outros filmes centrados em personagens femininos, Através da Janela (2000) e Antônia (2006) - este último a seguir transformado em série de televisão, compondo uma trilogia feminina já tornada referência para os estudos do cinema brasileiro. Tendo iniciado em meados dos anos 1980, no formato de curta metragem, Tata Amaral vem desde então mapeando o desenvolvimento da cidade de São Paulo, onde nasceu, com filmes militantes em defesa das minorias sociais, do meio ambiente e da liberdade de expressão artística.

Esta entrevista foi realizada em São Paulo, em 31 de janeiro de 2017, para o filme Passagens, dirigido por Lúcia Nagib e Samuel Paiva, como parte do projeto IntermIdia, que reúne pesquisadores da Universidade de Reading e da Universidade Federal de São Carlos, com financiamento da AHRC, no Reino Unido, e da FAPESP, no Brasil. Passagens focaliza um conjunto de filmes, originários principalmente de São Paulo e Pernambuco, nos quais dispositivos intermidiais, isto é, a utilização no cinema de outras formas artísticas, como pintura, teatro, música e fotografia, entre outras, funciona como uma "passagem" para a realidade social, histórica e política do país. Para a produção do filme foram entrevistados 15 cineastas, técnicos e curadores, que exerceram um papel central na Retomada do Cinema Brasileiro; dentre eles, Tata Amaral. No filme Passagens, ainda em preparação por ocasião desta publicação, as entrevistas serão editadas com trechos de filmes em que outras artes provocam uma fissura na virtualidade do cinema pela qual emerge o real fenomenológico. Desde o início de sua carreira, Tata vem

\footnotetext{
${ }^{1}$ Esta entrevista é um dos resultados do projeto IntermIdia, financiado pela AHRC e a FAPESP (www.reading.ac.uk/intermidia), às quais agradecemos. Agradecemos também à Universidade de Reading a qual contribuiu para o financiamento do filme Passagens pelo esquema BOISP (Building Outstanding Impact Support Programme).

${ }^{2}$ University of Reading, School of Arts and Communication Design, Department of Film, Theatre \& Television, Reading RG6 6BT, Reino Unido.

${ }^{3}$ Universidade Federal de São Carlos, Departamento de Artes e Comunicação, 13565-905, São Carlos - SP, Brasil.
} 
explorando outras formas artísticas em seus filmes, desde o uso de fotografias em Um Céu de Estrelas até sua recente série para televisão, Causando na Rua, voltada para o "artivismo", isto é, o ativismo artístico que intervém em espaços públicos na cidade de São Paulo. Esta entrevista dá destaque a momentos de seus filmes em que as relações com a fotografia, a música e o teatro, enquanto veículos para a realidade histórica e documental, são particularmente notáveis.

Um Céu de Estrelas abre com um curta-metragem de Francisco César Filho, assíduo colaborador de Tata Amaral. O curta é composto de fotografias históricas e imagens em movimento atuais da Mooca, bairro de passado industrial que teve papel central na expansão econômica do Estado de São Paulo a partir do final do século XIX. É também um bairro famoso pelas revoltas operárias do início do século $\mathrm{XX}$, tendo sido palco de ativismo comunista e anarquista. Documentando os resquícios desse passado de produtividade, luta e decadência, as fotografias atuam aqui como base histórica para a narrativa ficcional, cuja mola propulsora é a onda de desemprego dos anos 1980.

Já Antônia é um filme inteiramente centrado no papel da música como mecanismo de emancipação de um grupo de cantoras de rap e hip hop da periferia de São Paulo, especificamente a cidade satélite de Santo André e o bairro da Brasilândia: Negra Li, Leilah Moreno, Quelynah e MC Cindy. O filme enseja a formação de um grupo musical com as quatro cantoras, que nunca haviam atuado juntas, enquanto as expõe uma a uma como talento individual, desempenhando papel decisivo na carreira de todas elas. A música, aqui, serve não apenas como passagem para o real, mas também como interferência nele, e constitui ainda um antídoto contra a exclusão a que estão sujeitas mulheres negras e de extração humilde como elas. Em vista de sua originalidade e sucesso, o filme deu origem a uma série patrocinada pela produtora O2 e pela Rede Globo de Televisão.

Finalmente, a entrevista aborda Trago comigo, um longametragem originário de uma série para a TV Cultura, em que o teatro serve de laboratório para a reconstrução histórica dos crimes cometidos pela ditadura militar no Brasil (1964-1985). Telmo, um ex-guerrilheiro tornado diretor de teatro, desenvolve uma peça com o objetivo de preencher um lapso de memória sobre uma companheira morta em ação. Entre a confecção da peça e os ensaios, são intercalados depoimentos de sobreviventes reais da tortura, oferecendo, entre as brechas da ficção, a prova material dos crimes cometidos na época. O recurso ao teatro serve aqui também para a redescoberta do famoso Teatro Brasileiro de Comédia (TBC) de São Paulo, atualmente desativado: liga a ficção a um contexto geográfico real e rememora o papel central do movimento teatral paulista nas lutas políticas do país. 
Para esta publicação, a entrevista foi editada e acrescida de notas por Lúcia Nagib. Agradecemos a Debora Taño pela transcrição cuidadosa da entrevista completa.

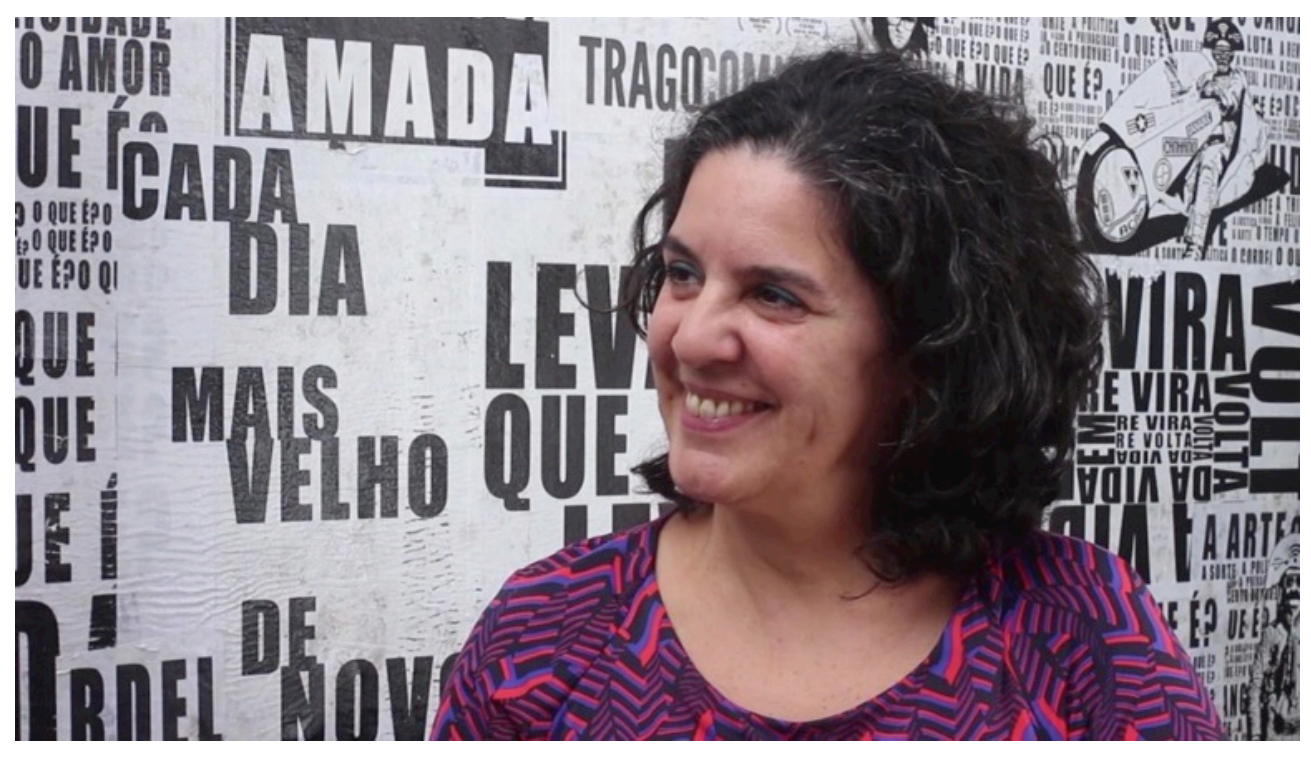

Imagem 1: Tata Amaral

\section{Um Céu de Estrelas (1997)}

Aniki: Um Céu de Estrelas é o primeiro longa-metragem que você dirigiu e que causou um impacto imenso em meio àquela geração que fez parte da Retomada do Cinema Brasileiro. Passados 20 anos, como você vê aquele momento?

Tata Amaral: Foi um momento muito especial para o cinema. Por um lado, havia uma polarização geográfica. Como não havia Internet, eu nem sabia que o Lírio [Ferreira] e o Paulo [Caldas] estavam fazendo Baile perfumado em Recife. Fiquei sabendo em Brasília. ${ }^{4}$ Eu sabia do filme da Carla Camurati [Carlota Joaquina, princesa do Brazil, 1995], no Rio, que é também da minha geração, mas que teve uma outra formação. Então o processo de gestação foi um pouco fechado e nessa época a gente não se conectava tão facilmente. O período da Retomada é um período em que quem retoma é principalmente a geração de curta-metragistas, da qual eu faço parte. Acho que da minha turma da ECA [Escola de Comunicações e Artes, Universidade de São Paulo] eu fui a primeira a fazer longa. Mas isso também não me importava na época. Tinha um desafio, que era fazer um filme, e eu tinha escolhido a história do primeiro livro do Fernando Bonassi. A gente participou de um edital de telefilme de baixo orçamento, que servia para mim, porque era uma raia que ninguém queria, porque era pouquíssimo dinheiro, só

\footnotetext{
${ }^{4}$ Em Brasília ocorre anualmente, em setembro, o Festival de Brasília do Cinema Brasileiro.
} 
100 mil reais. Entrei ali e ganhei. Aí, tinha que fazer o filme. Como fazer um filme trancado entre quatro paredes que não seja aborrecido? Era um desafio. Eu já estava pesquisando dramaturgia desde História Familiar, que é um curta que também acontece entre quatro paredes. A única janela é a televisão, como em Um Céu de Estrelas. O desafio é manter o interesse do espectador, trazer o thriller para dentro daquele lugar. Entre ganhar o concurso e conseguir produzir, acho que foram dois anos em que fiquei pesquisando dramaturgia.

Aniki: O filme tem uma espécie de prólogo filmado por Francisco César Filho, que começa com uma sequência de fotografias de imigrantes que estão vindo para São Paulo, para a região da Mooca. Há toda aquela sequência da região operária ali, com as fábricas, algumas delas em ruínas, e isso nos introduz no universo de Victor e Dalva. Qual a razão da sua decisão de trazer esse registro documental e intermidiático, ou seja, a fotografia desses registros históricos, antes do filme em si?

TA: O Chiquinho fez uma peça que é pura poesia em preto e branco. Não é exatamente documental, mas capta justamente esse ambiente da Mooca, que é onde se passa a história e de onde vem o Fernando Bonassi, autor do livro adaptado para o filme. Esse curta metragem que o Chiquinho fez capta essa situação de um bairro decadente que foi operário entre os séculos XIX e XX. Naquele momento dos anos 1990, ainda havia resquícios do grande desemprego da década de 1980, o que se reflete nos personagens do filme. Está tudo meio dito ali de uma maneira muito alusiva e o urbano é muito forte também. A Mooca tem uma identidade muito forte.

Aniki: Jean-Claude Bernardet colaborou no roteiro e é um colaborador seu em vários projetos. O argumento de seu filme seguinte, Através da Janela (2000), é dele. Ele é também uma referência para a história do cinema brasileiro, com vários livros publicados a esse respeito. Como é que foi seu trabalho criativo com o Jean-Claude, alguém que tem essa visão histórica do cinema brasileiro?

TA: Foi muito especial, muito inesperado. Um Céu de Estrelas teve várias levas de roteiristas e eu não ficava satisfeita, porque eu queria alguma coisa muito radical. Acho que eu queria o que aconteceu. Imagina um filme low budget, contratando roteiristas, pagando e não usando. Era uma tensão, também. Pedi para o JeanClaude ler um dos roteiros com o qual eu ainda não estava satisfeita. Eu não tinha intimidade com ele. Já tinha ido a uma ou duas palestras dele, mas eu queria a sua visão como crítico e como professor de roteiro que ele era. Disse a ele que no livro a personagem feminina era muito apagada, opaca. Funcionava no livro, mas no filme tinha que ter os dois ali de carne e osso, e os dois funcionando. Seria 
possível, e seria mesmo radical, criar um personagem desfocado literalmente, mas eu não queria isso, eu queria fazer crescer o personagem feminino e equipará-lo ao masculino. Então, o JeanClaude me propôs trabalhar em sala de aula com o Roberto Moreira, que era o professor assistente dele, sobre um dispositivo básico, que era inverter o ponto de vista narrativo do homem, tal como estava no livro, para a mulher. Fez isso com tamanho rigor que nenhuma cena foi filmada a não ser através do ponto de vista da Dalva. Ou seja, se algo está acontecendo lá fora, o espectador só sabe quando Dalva sabe. Então, a contribuição do Jean-Claude e do Roberto foi imensa. Eles construíram um filme com a radicalidade que eu estava buscando e não estava encontrando. Realmente fiquei muito feliz. Praticamente filmei o roteiro todo - em geral, eu estou sempre mexendo -, com exceção do final, que desde o começo imaginei que fosse da maneira como é. Ou seja, a câmera entrando na televisão, que se configura como uma janela na qual vemos a cena do ponto de vista de quem está fora da casa (onde estão os personagens principais), enquanto ocorre o cerco policial ao redor da casa. E a câmera entra dentro da televisão e, quando a câmera da televisão entra dentro da casa, encontra a cena modificada, tal como a câmera de cinema havia deixado. Então é quase um círculo sem ser. Isso eu tinha imaginado desde o princípio. E não houve meio de o JeanClaude e o Roberto me convencerem a fazer diferente.

Aniki: Pegando justamente essa sequência que você fez questão de manter, e é fundamental no filme: a televisão como uma mediação do espaço íntimo da casa onde o drama está acontecendo e o espaço público aonde esse drama se projeta. Por que era tão importante para você essa solução dramática, com a televisão ocupando esse espaço de mediação entre o público e o privado desses personagens?

TA: Porque um acontecimento havia me chocado muito. Hoje não choca mais, porque a televisão virou paraticamente isso. Mas tinha acontecido um marco na televisão cerca de um ano antes das filmagens, que foi o programa "Aqui, agora" filmar um suicídio no centro da cidade. Eu não vi porque vejo muito pouca televisão, mas me lembro que as notícias de um programa ter filmado um suicídio me chocaram muito. Eu falava: "gente, como é que você filma um suicídio e não faz nada para preservar a vida daquela pessoa?" Ainda mais chocante era o fato de os espectadores julgarem ou ficarem presos àquela tragédia de uma maneira que eu achava indecente. Então, quando acontece o cerco policial no filme e a televisão chega, eu quis explorar esse sensacionalismo. Tanto que a inspiração para a atriz Lígia Cortez, que faz a repórter de TV, eram esses repórteres sensacionalistas que cobriam esse tipo de programa que hoje não é chocante, como eu disse, porque a televisão se transformou, o jornalismo diário se transformou nisso, mas que ficava ali o tempo todo, tentando arrancar alguma espécie de notícia de uma pessoa que 
estava trancada com uma outra dentro de casa. Um drama pessoal explorado ad nauseam pela imprensa para o gosto da opinião pública vampiresca. Essa dicotomia é geográfica, porque tem a casa, o interior e o exterior, mas a televisão media desta forma, na minha opinião, completamente vampiresca, sem valorizar, ou sem olhar, sem ter um pingo de solidariedade com o drama pessoal que estava acontecendo, que é o que o filme mostra, explorando sensacionalisticamente a sua pior faceta. Quando a câmera da TV entra dentro da casa junto com os policiais e encontra o drama, só resta o silêncio. É como se eu tivesse convencendo a opinião pública a olhar a cena íntima com humanidade. Quase uma utopia mesmo.

Aniki: Algo impressionante no filme é o trabalho de som de Eduardo Santos Mendes, João Godoy e Valéria Ferro. Em alguns momentos é da referência sonora que vem o drama. Inclusive no momento em que ocorre o tiro, que é muito importante dentro da história que está sendo contada. Qual foi a sua orientação para a equipe de som neste filme?

TA: Em primeiro lugar, a gente sabia que ia construir um filme com um universo sonoro fora do quadro. Isso era muito, muito importante, porque eu já queria essa cidade através das luzes que vêm de fora, a partir de um determinado momento, quando acontece o cerco policial. No caso do som direto, eu disse: "João, não tem a menor possibilidade de você não fazer esse filme". Ele estava ocupado, ia fazer outra coisa. Ele ia colocando empecilho e eu dizia: "esse eu resolvo assim, esse eu resolvo assado", porque eu realmente queria o João, pelo rigor que ele tem na captação do som direto, e eu queria o filme inteiro em som direto. Essa característica do trabalho do João é muito importante para mim. Eu queria um som direto de qualidade. Porque muitas vezes o microfonista tem o lapela e tem o boom. O boom capta a espacialidade com toda a sua riqueza, para o bem e para o mal, porque passa avião, tem cachorro latindo, etc. Tem sons que muitas vezes não interessam à cena. E o lapela garante a limpeza da voz. E eu estava fazendo um filme em que as pessoas tiram a roupa, ficam nuas. Não tem como ter lapela. Então eu precisava realmente de uma construção rigorosa para garantir a eficácia do som direto, captado através do direcional. Então, a casa inteira foi trabalhada. O chão era de madeira, foi feito um tratamento para amortecer. A casa estava sendo reformada, a gente alugou essa casa, e o teto a gente forrou também, mas as vigas estavam abertas. Às vezes a Valéria Ferro, a microfonista, ficava pendurada nas paredes, porque tinha um espaço entre as paredes e o telhado, com o microfone em cenas que eram 360 graus, que não cabia. Então a cumplicidade da equipe nesse sentido foi muito importante, de topar esse desafio de captar tudo em som direto, sem lapela e com qualidade, e sem dublar. E depois, é claro, a edição de som do Edu Santos Mendes, que cria todo esse universo fora da tela com mil histórias, desde o começo tem um mundo acontecendo. 
Aniki: Este é o primeiro filme da atriz Leona Cavalli, fazendo um personagem muito forte, que ganha mais ênfase no filme do que no romance do Bonassi. Foi uma interpretação física muito forte, tanto dela como do Paulo Vespúcio, mas dela sobretudo, como protagonista dessa história. Como foi esse trabalho com a Leona Cavalli, que vinha do teatro Oficina, e veio a se tornar uma atriz muito importante do cinema brasileiro a partir daquele momento, aparecendo por exemplo no filme pernambucano Amarelo manga, de Cláudio Assis? Como foi essa descoberta e o trabalho com ela?

TA: Acho que você mesmo deu a chave. Ela tem um trabalho físico. A Leona realmente consegue, o corpo dela trabalha como um todo. Ela tem uma entrega muito grande. Eu tinha visto a Leona fazendo Ofélia no teatro Oficina, com essa entrega absurda. Era Inverno, e Ofélia se suicida se jogando na cachoeira, e lá tinha um tanque e ela, naquele frio, nua, com um cabelo imenso, naquela água. Foi uma cena memorável da Leona, fazendo essa Ofélia. Então, eu sabia que era uma pessoa cuja epiderme poderia ser impressa no filme. E aliado a isso eu queria um câmera que trouxesse essa possibilidade de filmar esses atores. Minha inspiração era o Dib Lutfi, no Cinema Novo, que faz aquelas câmeras na mão. Isso eu tinha certeza, eu queria câmera na mão. E veio o Jacob Solitrenick, que estava começando a fazer câmera, nunca tinha feito câmera na mão assim desse jeito. E eu: "Jacob, vamos?" "Vamos". Porque eu queria a respiração do fotógrafo em todas as cenas. Foi aí que a gente começou a construir essa cumplicidade que dura até agora. Vou fazer o primeiro filme agora sem o Jacob. Ontem, minha filha ${ }^{5}$ perguntou: "mas como você vai fazer, mãe, um filme sem o Jacob?" E eu falei, "olha, também não sei."

\section{Antônia (2006)}

Aniki: Antônia, um filme tão significativo em termos de combinação de música e cinema, tem um tom documental que aparece desde aquele primeiro plano da câmera, que pega a favela de cinema e vai baixando até enquadrar os personagens femininos, as cantoras Negra Li, Leilah Moreno, Quelynah e MC Cindy, que emergem no topo de uma rua em aclive com a paisagem da favela no morro ao fundo. Essa tentativa de contextualizar a narrativa ficcional no real poderia ser considerada uma marca do seu estilo?

TA: Com certeza, porque é uma maneira de trabalhar. Eu gosto de montar a cena e deixar a câmera livre para estabelecer com a cena um comportamento documental. Eu marco algumas coisas com os atores e com o fotógrafo e tem um desafio, uma provocação para que ambos, e também o microfone, fiquem atrás da cena, para que eles tenham um comportamento diante da cena. Para isso, a

\footnotetext{
${ }^{5}$ Caru Alves de Souza, filha de Tata Amaral, é também cineasta.
} 
parceria que desenvolvi, entre outros, com o Jacob Solitrenick e com o João Godoy tem sido muito importante.
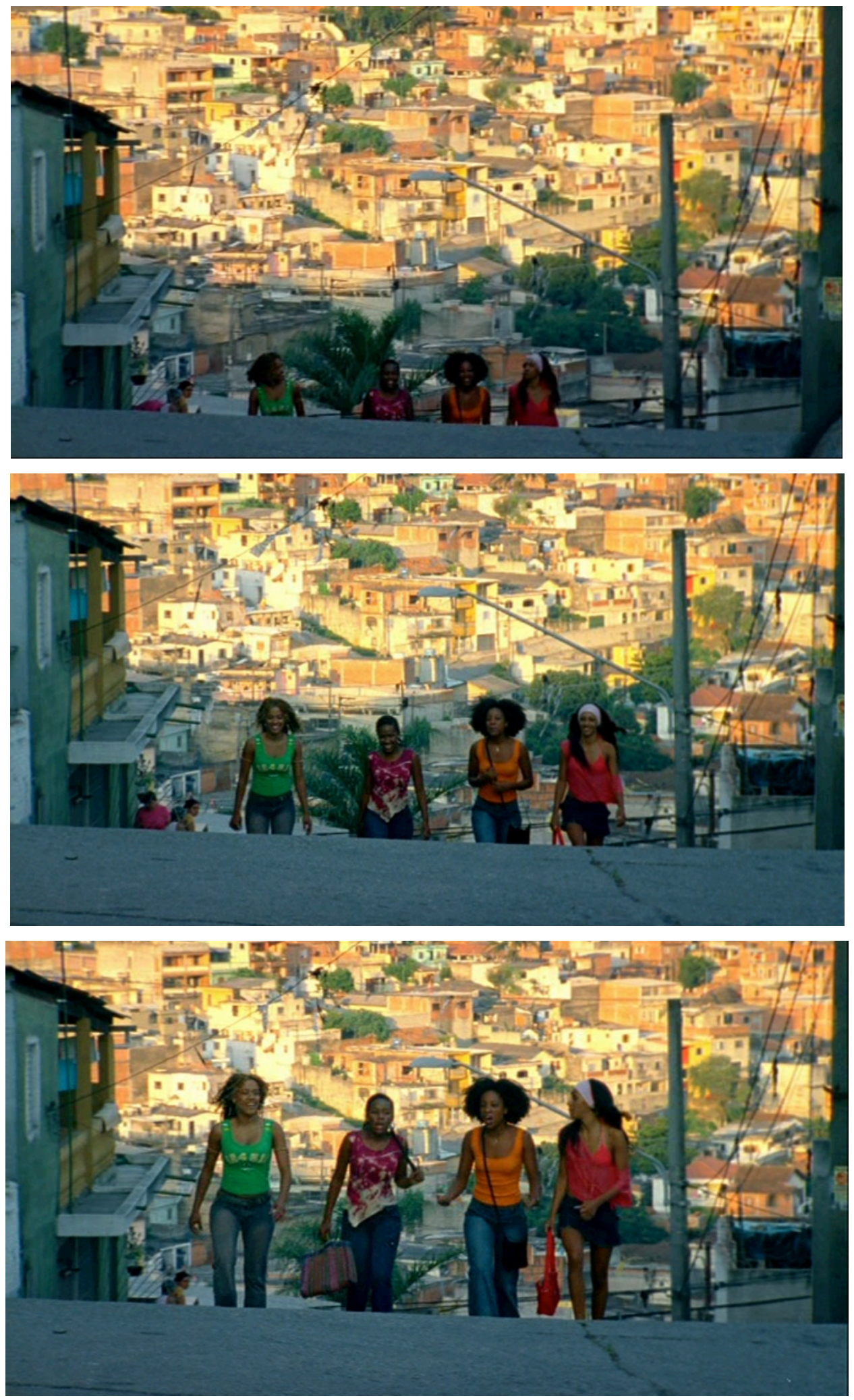

Imagens 2, 3 e 4: Antônia (2006) 
Aniki: Então, nesse sentido, a escolha da locação em si é tão importante quanto a seleção do elenco.

TA: Exatamente. Para mim, locação é tudo.

Aniki: Na realidade, alguns dos personagens ali, das cantoras que você selecionou, vinham da Vila Brasilândia, que é mencionada como tal ao longo do filme inteiro.

TA: É, filmamos na rua de esquina de onde a Negra Li morava, onde ela nasceu, cresceu. E o filme, sim, ele buscou valorizar o bairro, o lugar. O tempo todo a Brasilândia foi mencionada, nas músicas e nas conversas entre os personagens. E a ideia era essa mesmo. A Brasilândia, eu dizia na época, é o bairro mais cinematográfico que há, pela sua condição geográfica especial. Onde a gente escolheu filmar é uma espécie de estádio, uma cratera de vulcão que é o começo da Cantareira e você tem uma baixada que vai até o Rio Tietê. E ao longe você vê o espigão da avenida Paulista, que começa no Jabaquara e vai até o fim da rua Cerro Corá e boa parte dele estava ali no nosso cenário. No entanto, embora tenha sido palco das filmagens de Eles não usam Black-tie (Leon Hirszman, 1982), O invasor (Beto Brant, 2002), De passagem (Ricardo Elias, 2003) e tantos outros, ela sempre representou a periferia, nunca um bairro. Até então ela representava a periferia no cinema e eu quis dar o nome desse bairro. Eu gosto disso. É a Mooca, é a Lapa, é a Brasilândia, é o Capão Redondo. Isso acabou agora sendo muito acentuado, essa ideia geográfica da cidade de São Paulo, nas séries que estou fazendo sobre ativismo artístico na rua, onde tem até o mapa de deslocamento, onde eu faço questão que as pessoas entendam a imensidão da cidade através dos deslocamentos possíveis.

Aniki: E qual o papel da música? Qual era a importância de os atores do filme serem cantores na realidade? Eles não estão imitando, não estão sendo dublados. As próprias cantoras cantam músicas que muitas vezes são compostas por elas também. Qual é o papel da música nesse encontro entre cinema e um real documentário?

TA: Bom, o filme é praticamente um musical e a música busca avançar a narrativa, partir dela. A música entra e depois, quando termina, a gente retoma a narrativa a partir daí, não volta ao ponto anterior ao episódio musical. Eu busco avançar. Esse é um dos dispositivos que eu introduzi. Alguma coisa aconteceu no episódio musical que fez a história avançar. Outro dispositivo muito importante eu compreendi em 2001, quando fiz um filme chamado Vinte/Dez, um documentário sobre a juventude do hip hop da periferia de Santo André. Eu aprendi que no rap não tem intérprete. No rap, o MC, o mestre de cerimônia, fala em nome próprio, ainda que esteja contando a história de outra pessoa. "Meu nome é Tata e eu vou falar sobre a minha amiga Lúcia e o que aconteceu com ela". 
Então ele explicita o ponto de vista. Acho importante em tudo, na arte quanto no jornalismo, explicitar o lugar de onde se emite o discurso. Hoje tem a expressão muito comum, que é o lugar de fala que mais ou menos vale para tudo, mas eu acredito muito no lugar que você ocupa e do qual fala. E nisso a minha fala é diferente da sua - e aí está a diversidade de todos nós. O respeito a esse lugar para mim é muito caro. Encontrei no rap essa máxima de que quem fala, quem canta é o autor, não é o intérprete. Isso é uma coisa; a outra coisa é que, com isso, eu deixei de escrever os diálogos. Ou melhor, eu escrevia os diálogos, mas não passava para os atores. Porque eu queria que eles construíssem os diálogos, assim como eles construíram as músicas. Então, já na seleção dos atores, uma das coisas que eu avaliava era a capacidade de improvisação, a capacidade de criação de diálogos. Isso foi para todo elenco, inclusive os DJ. Ou seja, eles tinham que se apropriar do discurso. Uma outra preocupação em relação a isso, que também tem a ver com a música, era que a fala fosse legítima e original. E também a sintaxe e a gramática. Eu tinha muito medo de dar um diálogo escrito por mim, que venho de um bairro e de uma cultura de classe média branca, e que na ocasião tinha 45 anos. Eu tinha muito receio de que as pessoas se apropriassem de um texto que era meu e não delas. E, para isso, eu fui estudar um pouquinho também da história da fala de São Paulo. Eu contava muito para as meninas, para eles todos, que aqui em São Paulo se falava errado. A gente falou tupi até pouco tempo atrás, e a fala da periferia é do interior de São Paulo acrescida das novidades dos imigrantes de todas as origens. Então, "as coisa" é legítimo. Porque é errado? Porque, posteriormente, uma elite que estudou na França, que foi estudar sintaxe portuguesa, se apropriou disso e tornou essa fala hegemônica; mas até então falávamos tupi, depois do tupi a gente mais ou menos misturava com o português. Tem cartas de Dom Pedro I para Domitila ${ }^{6}$, tirando sarro dela por falar errado. Tem poetas que vinham estudar aqui na Faculdade de Direito, tirando sarro das meninas da elite paulista de então, que falava errado segundo eles. Então eu não queria essa ideia do certo e do errado, eu queria o legítimo. E o rap permite isso. O MC, o compositor e o cantor são a mesma pessoa. Isso eu extrapolei para os diálogos como um todo, com o intuito de valorizar a legitimidade, em vez do certo e do errado. Porque a língua é uma coisa dinâmica. $\mathrm{O}$ vernáculo está lá, mas aqui está acontecendo um monte de coisa. E em especial os jovens da periferia são muito criativos com a linguagem e eu queria isso para o filme e a música do filme.

Aniki: Neste sentido, há uma sequência que me emociona particularmente, quando Marcelo Diamante leva Preta para comer um cachorro quente e pergunta para ela: "O que você tá vendo?", e ela, "tô vendo o cachorro quente". Ele diz: "Não, olhe isso, olhe

\footnotetext{
${ }^{6}$ Domitila, ou Marquesa de Santos, tornou-se famosa na história do Brasil por seu envolvimento amoroso com o imperador Dom Pedro I.
} 
aquilo, olha o céu, enfim, observe a realidade de um ponto de vista mais interessante". E ele coloca no carro uma música para tocar, que é "Na sombra de uma árvore", do Hyldon, e nesse momento vem essa disposição que vai fazer com que as cantoras se reencontrem, depois de terem passado por problemas e dificuldades. O filme tem uma perspectiva otimista a partir dessa ideia de uma arte que vem de um contexto muito difícil e que, de alguma forma, se remete a uma tradição do próprio Cinema Novo, quando vai filmar o samba, ou artistas da Tropicália, como Oiticica, quando sobe o Morro da Mangueira e vê um potencial ali. Você acha que dá para pensar o filme nessa conexão com a perspectiva de um potencial artístico?

TA: Sem dúvida, eu tenho certeza de que na periferia acontece muita arte. Há produtores e também consumidores. O que eu sinto que acontece hoje é que muita dessa arte não chega aos meios de comunicação, fica ali circunscrita e não chega a nós da classe média; então, a gente tem a sensação de que não acontece nada. Mas quando você vai olhar, você vê que tá acontecendo tudo. Um exemplo disso é essa série que estou fazendo, Rua, que virou Causando na rua, cuja segunda temporada focaliza o "artivismo", ou seja, o ativismo artístico, que são intervenções que acontecem na rua e agora estão sendo criminalizadas pelo novo prefeito. O que me motivou na verdade a fazer Antônia, e tem muito a ver com o documentário Vinte/Dez, foram dois acontecimentos. Primeiramente, uma entrevista que fiz com uma menina de Santo André, a Shirley, que me disse: "Eu cresci com complexo de inferioridade, porque meu ídolo era a Xuxa. Só que a Xuxa é alta, loira, cabelo liso, magra e linda. Eu sou baixinha, gordinha, cabelo crespo" - e ela não se achava linda, mas era linda. Então, essa ideia de não haver referências positivas para a mulher negra era assustadora. Em segundo lugar, houve uma outra entrevista no Vinte/Dez de um rapaz que dizia: "Nós somos os PPP, preto, pobre, da periferia. Concentramos tudo que é ruim na sociedade: o bandido, o traficante, o pobre, o doente e tudo mais." De novo, um problema de falta de referência. Então, Antônia veio um pouco como uma resposta a isso, para propor uma nova representação. Eu também fui muito influenciada pelo filme do Joel Zito Araújo, A Negação do Brasil, que trata das representações dos negros nas telenovelas. É um filme chocante. Você vê como as pessoas eram representadas naquela ocasião e não mudou muito hoje. Mas a inspiração básica era que eu estava construindo uma trilogia do feminino, desde Um Céu de Estrelas e Através da Janela. Antônia é o recomeço, a mulher jovem. Construí Antônia a partir da ideia do nascimento da mulher para o coletivo, que é a adolescência, quando a gente sai de casa e vai para o mundo.

Aniki: Antônia se transformou numa série de televisão em canal aberto. Você acha que hoje há uma presença mais contundente da cultura negra na mídia brasileira, considerando que no próprio 
filme tem a presença do DJ Thaide, que teve um programa sobre hip hop na MTV? Você acha que, de alguma maneira, o espaço midiático está se tornando mais democrático, no sentido de inserir a cultura negra?

TA: Eu não tenho certeza de que a cultura negra está mais inserida. Eu gosto de números, porque quando você tem os números você deixa de "achar". A gente não tem os números relativos aos personagens negros nas novelas, as protagonistas negras, os autores negros, os diretores, as diretoras negras, essa pesquisa precisa ser feita. Em termos de autor negro, não me ocorre nenhum. Então, essa representação, se existe na dramaturgia televisiva, está sendo construída por pessoas que não são negras, são brancas, como ocorre em Antônia. No caso das mulheres no cinema, as últimas pesquisas sobre a presença da mulher na direção e no roteiro dos filmes de grande bilheteria apontam um resultado chocante: somos $19 \%$. E isso porque a gente acha que está numa condição melhor. E recentemente eu estive numa conversa na criação da APAN, Associação dos Profissionais do Audiovisual Negro, e o que eles falam é que, se a mulher branca quase não tem espaço no cinema, a negra não tem nenhum. Existe uma dívida histórica que ainda precisa ser saldada.

Aniki: Voltando àquela questão do emissor do discurso no rap e no hip hop, da autorreferencialidade do discurso em primeira pessoa que você caracterizou tão bem. Também existe um gosto pelas listas. Em Antônia, há um rap sobre a Brasilândia que faz uma lista das várias favelas de São Paulo, que me lembrou o filme $O$ Rap do Pequeno Príncipe contra as Almas Sebosas (Paulo Caldas e Marcelo Luna, 2000), e aquela famosa cena em que o Mano Brown identifica as favelas de Camaragibe com favelas de Belo Horizonte, do Rio de Janeiro, de Brasília e de São Paulo. Existe então essa tentativa de universalizar a favela como representação do Brasil e você usou a palavra representação "legítima". Gostaria de saber se você também trabalha um pouco nessa chave.

TA: Sempre. Eu acho que quanto mais particular a gente é, maior a possibilidade de alcançar a universalidade. Em Um Céu de Estrelas, por exemplo, era a Mooca, um personagem de origem operária. Isso é só lá e na Lapa que existe. Porém, a gente consegue tocar as pessoas, porque o particular é humano e humano todo mundo entende. Em relação específica à favela, elas são na verdade cada vez mais bairros, e são sim universais na condição geográfica, estão sempre à margem do centro, e também são de certa forma universais na sua condição de franja e exclusão, principalmente em São Paulo e outras grandes cidades brasileiras. Se você pensar no subúrbio nos Estados Unidos, a periferia é a zona rica, onde estão as grandes casas, na maior parte das cidades. Em São Paulo e outras cidades brasileiras, o subúrbio, o que a gente chama de periferia, é periferia mesmo. Onde o ônibus só chega para transportar a pessoa 
para o trabalho. Os horários, tudo é calculado para que a pessoa sirva de mão de obra da região central. Então, acho que, nesse sentido, sim, é universal. Porque tem a mesma função social e a mesma expulsão. Brasilândia tem uma característica muito específica. Quando você olha os bairros, eles têm uma história e essa história é muito bonita. A Brasilândia começou a ser ocupada a partir dos anos 1940 , quando as pessoas pobres foram expulsas do centro de São Paulo pelo projeto Prestes Maia e, por coincidência, lá havia pedreiras que forneciam material para a construção das grandes avenidas de São Paulo. Na verdade, se a gente olha para periferia a gente enxerga uma história que precisa ser contada e valorizada.

Aniki: Além da questão da periferia, da mulher, da raça, Antônia ainda aborda outras minorias, os homossexuais, os deficientes físicos e a falta de preparo local para deficientes: o rapaz quebra a perna e não consegue mais chegar em casa e, naturalmente, a questão do preconceito sexual está na origem do ferimento dele. Você acha que seu filme, abordando todas essas minorias, corria um pouco o risco de se tornar excessivamente programático?

TA: O programa não veio antes, foi aparecendo. Precisávamos de uma situação em que o grupo das cantoras fosse se desfazendo. Então, precisávamos de situações dramatúrgicas. Durante todo o tempo em que eu fiquei levantando financiamento para o filme, visitei vários bairros, quis conhecer as rappers, as mulheres que batalhavam artisticamente das mais variadas formas, e acabei tocando na questão da homossexualidade na periferia. E foi muito chocante quando uma das pessoas que entrevistei disse: "Na favela não tem matizes de sexualidade. Ou você é a bicha da favela ou você não é. E você não pode ser o enrustido, porque isso dá morte. Você vai andar com seus amigos homens, se eles descobrem que você é gay eles ficam putos, porque eles estão andando com um gay". Acho que evidentemente isso está mudando, a gente vê pelos coletivos trans, mas ainda falta muito. E quando o Roberto Moreira, que é o co-roteirista do filme, perguntou: "Então a Bárbara sai do grupo e fica sozinha?” Então, criamos o irmão da Bárbara. Mas a perspectiva não era trazer a discussão da sexualidade, isso entrou pelo meu olhar, principalmente.

Aniki: A Bárbara tem traços masculinos também. Essa personalidade dela não é explorada no filme, mas a gente pensa que o próximo passo seria ela se revelar. E ela é presa, o que te dá oportunidade de explorar o universo da prisão como parte do cotidiano dos moradores da periferia, e é uma experiência que talvez seja próxima de você, em razão da sua história de engajamento político, que poderia ter te levado à prisão. Mas na favela é outra coisa, é a criminalidade comum que acaba fazendo com que a maioria dessa população tenha alguma experiência com relação à prisão. Como você lidou com isso, como você fez a pesquisa para chegar até aí? 
TA: A pesquisa foi exatamente isso que você falou. A presença da prisão, todo mundo tem alguém na prisão. E não necessariamente porque de fato são criminosos. A polícia e a cadeia são tão comuns na periferia quanto são no final de Antônia o cabeleireiro, o curso de inglês e o de eletrônica. Em 1999, quando comecei a pesquisar para o filme, a paisagem era assim: após o almoço, você via vários homens sentados na soleira, em geral desempregados. No final do dia, começavam a chegar as mulheres com sacolas. E no filme, a gente marcava o horário por esta configuração. Isso não é dito, não é problematizado, mas está lá, na definição do movimento das ruas. E à noite, as famílias entram para dentro de casa e os jovens, quando muito, circulam. As ruas ficavam vazias muito antes de serem tomadas por essas facções que hoje dominam a periferia, mas já num momento de grande evangelização. Entre o filme e a série, aconteceu uma enorme mudança da paisagem urbana. Eu filmei no começo de 2005 a primeira temporada da série e a segunda em 2007. Você lavava a louça na casa da Bárbara e via São Paulo, o espigão da Paulista ao longe, ali da pia lavando louça, e só havia casa de tijolo aparente. Já em 2007, isso já não era possível, devido à explosão imobiliária. Antes, você via as casas muito bem cuidadas, azulejadas, pintadas por dentro e tijolo vermelho por fora, mas isso mudou, as casas passaram a ter reboco e pintura por fora. O curso de eletrônica, de inglês e o cabeleireiro explodiram, quer dizer, a prosperidade da segunda metade dos anos 2000 chegou e modificou o cenário. E os homens já não estavam mais na soleira, porque estavam trabalhando. $\mathrm{E}$ a polícia passou a ser mais presente e, mais recentemente, multiplicaram os assassinatos.

Aniki: Existe esse aspecto que beira o utópico, num filme centrado em mulheres, que é a inexistência de droga e violência. Os crimes a mão armada também não existem, ao contrário dos filmes de favela que conhecemos, no estilo de Cidade de Deus e outros que vieram na esteira, onde a violência de perfil masculino impera e determina toda a ação. É interessante você falar que a violência começou a crescer após o filme. Mas ela já não estava lá presente? Em que medida isso corresponde a uma situação real, e o quanto é uma aspiração?

TA: Há uma situação real em que, em primeiro lugar, a violência é masculina, sobretudo. Quem é perseguido, o grande alvo policial são os jovens negros da periferia. As mulheres não tanto. Então, isso é um dado e o filme focaliza um universo feminino. Segundo, existe todo um universo onde essa violência não acontece de uma forma tão caricatural como alguns filmes tratam. Acho que faz parte da construção do preconceito você constantemente associar a violência, o tráfico, à juventude negra. Tenho certeza disso. Em Antônia, utopicamente ou não, eu busquei trazer um outro universo que é também verdadeiro, que pode ser um universo exclusivo das mulheres, mas acho que não necessariamente. Agora 
essa configuração toda, depois de 2006, muda radicalmente. Começa o crescimento da presença da polícia nas periferias, da criminalização, das facções.

Aniki: O final é apoteótico, uma apoteose feminista, digamos assim, porque é a música "Antônia" e todo mundo cantando junto uma letra muito afirmativa do poder da mulher. E existe uma ambiguidade sobre se esse final é algo que acontece na realidade ou wishful thinking do Marcelo Diamante. Ele tem aquela visão, sendo que a realidade é o concerto na prisão. Como você se coloca nessa visão, e como foi que você planejou esse final?

TA: Na verdade, veio depois do filme montado, porque o filme mesmo acabava ali na prisão. Só que a gente olhou e falou, "tá um pouco caído, né?", e não era a ideia. O elenco não conhecia o roteiro. Eles se dispuseram a chegar todo dia, propúnhamos improvisações e aos poucos a gente ia construindo o que ia acontecer, junto com o Sérgio Penna, que foi o preparador do elenco. Foi um trabalho muito intenso e minucioso. Quando chegou no final desse programa de improvisação, elas conheceram, e eles também, o final do filme. E foi uma decepção porque eles acharam que iam fazer um sucesso estrondoso e o filme acabava na cadeia. Então reescrevemos o final, e a fala do Diamante foi gravada depois, quando ele diz: "vocês estão vendo o que eu tô vendo? Mas eu tô vendo uma outra coisa", e vem aquele showzão incrível que a gente filmou lá antes de tudo.

\section{Trago comigo (2016)}

Aniki: Trago comigo é um filme que se liga ao momento atual da conjuntura brasileira e também ao progresso da Comissão Nacional da Verdade, que foi criada em 2012 e que, por um lado, tem ajudado a reconstruir a história da ditadura militar, mas a punição dos responsáveis é quase nula. Como você vê esse filme se inserindo e contribuindo talvez para algum tipo de avanço político?

TA: Pois é, em primeiro lugar, o filme foi filmado em 2009 como uma série originalmente feita para a TV Cultura, de quatro episódios. Foi praticamente um dos primeiros convites que eu recebi na vida. Para mim, tinha sido sempre batalhar o dinheiro, realizar, lançar, etc. Ali alguém me convidou para fazer, e foi o núcleo de dramaturgia da TV Cultura, o Gabriel Priolli e o Pedro Vieira. Eu disse que aceitaria, desde que pudesse trabalhar o universo dos presos políticos, dos anistiados e das sequelas que eu já estava trabalhando para realizar o filme Hoje. O que me interessava era hoje, não contar uma história que estivesse no passado. Eles toparam, e então o Matias Mariani apresentou esse argumento sobre um ex-preso político, que é diretor de teatro e descobre que tem lacunas na memória, relacionadas ao seu passado de preso político, e resolve fazer uma peça para se lembrar. Como vocês sabem, fiz parte 
do movimento estudantil na segunda metade dos anos 1970, sou uma pessoa interessada, politizada; mesmo assim, tive várias surpresas ao pesquisar para esse filme. Uma das grandes surpresas foi me dar conta de que, embora muitos militantes estivessem mortos, muitos ainda estavam vivos para contar a história. Então, eu quis no filme provocar essa espécie de surpresa, ou pelo menos de constatação, trazendo as pessoas que a gente estava entrevistando, que o Matias Mariani estava entrevistando, para dentro da história. Articular isso também teve a mesma preocupação que para a música no Antônia, ou seja, quando os depoimentos reais entram, eles não entram para parar a história, eles entram para avançar. Em 2009, o que eu queria era contar para as pessoas que aquilo tinha acontecido fazia pouco tempo. E a série foi feita antes da criação da Comissão da Verdade. Em 2009, havia uma batalha pela investigação, e não havia gente querendo que a ditadura acontecesse novamente, como hoje. Então, a atualidade do filme em 2016, quando o filme foi lançado, é trágica. $\mathrm{O}$ que eu estava querendo era simplesmente falar que a gente não pode andar para frente sem olhar para nossa história, porque ela repercute no nosso presente. Por nunca se ter dado nome às pessoas que cometeram crime de tortura, esses crimes nunca foram investigados e nem punidos, são crimes que assombram até agora. A gente estava recentemente falando da presença policial na periferia, os dispositivos policiais mobilizados hoje são exatamente os daquela época. Sequestro, ocultação de cadáver, execução sem julgamento, atraso em julgamento, não-julgamento. Ou seja, não se trata de vingança ou de revanchismo, se trata de hoje.

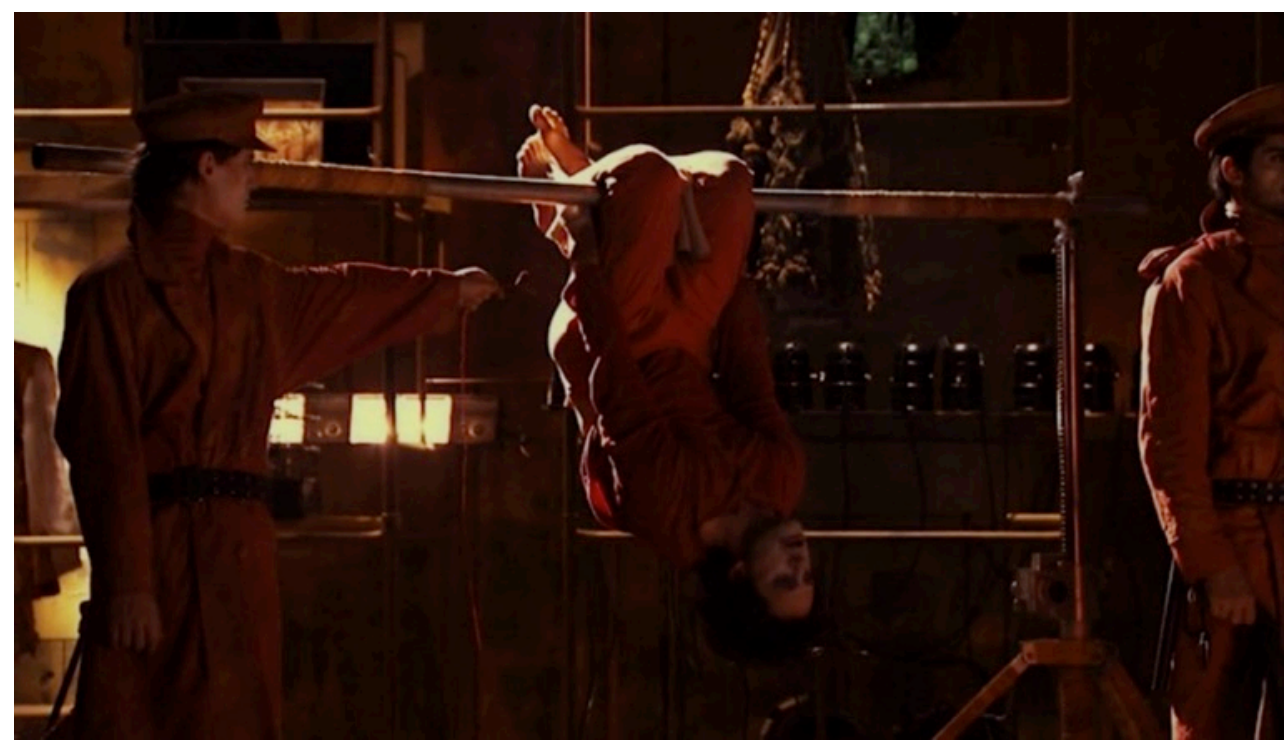

Imagem 4: Trago Comigo (2016)

Aniki: O projeto começou na televisão e houve essa passagem para o cinema. Como foi lidar com as duas experiências? 
TA: Na televisão, ele teve uma repercussão muito legal e teve a sua função naquele momento, que é contar essa história, falar: "gente, vamos lembrar". A série foi apropriada pelos movimentos dos familiares de presos políticos e as pessoas que batalhavam pela Comissão da Verdade, pelo julgamento dos crimes. E foi isso que me motivou a fazer o filme. Daí é um processo, consegue uma finalização da prefeitura lá em 2011, aí mais um dinheirinho do Governo do Estado em 2015, e assim a gente foi montando. Notamos também que muita gente mais desavisada que não conhece a história - e muita gente que vê o filme não conhece a história - não sabe quem são aquelas pessoas. E como o filme e a série começam com o depoimento do personagem do Telmo, interpretado pelo Riccelli, as pessoas acham que os outros depoimentos são de atores também, então aos poucos vão percebendo que não são. Esse é um dos dispositivos que se mantiveram na série e no filme. Outro é que, quando as pessoas reais mencionam o nome de quem as torturou, colocamos uma tarja e tiramos o som. Ao fazer a série, eu me dei conta de que esses torturadores nunca foram punidos e que, portanto, seria calúnia acusá-los. E no filme, quando eu já tinha me dado conta de que jamais seríamos processados, porque bastava alguém processar para vir um monte de gente dizer, "não, eu estava lá, eu vi, você me torturou”, esse se tornou um dispositivo para expressar o interdito. Achei que seria mais eficiente exagerar a tarja para chamar a atenção do público para o fato de que até hoje essas pessoas não foram julgadas. A única pena é que entre finalizar o filme e o lançamento, o Carlos Alberto Brilhante Ustra foi reconhecido como torturador. Nunca foi julgado, não pagou pelos seus crimes, morreu antes disso, mas foi reconhecido. É a única pessoa no Brasil reconhecida como torturador. Então, o seu nome poderia não ter tarja.

\section{Aniki: Reconhecido legalmente?}

TA: Legalmente, pelo Supremo Tribunal Federal.

Aniki: Nesse processo de trazer de volta a memória perdida desse diretor de teatro, você também traz de volta teatros em São Paulo que foram desativados. Porque muitas dessas manifestações políticas aconteceram em teatros, no Arena, no Oficina, e isso volta muito claramente à nossa vista, é muito significativo aquele ato de ressuscitar um teatro fechado. Você poderia elaborar um pouco sobre a escolha desse tema?

TA: O tema teatro veio principalmente em função dos poucos recursos financeiros que a gente tinha. Trago comigo, mais que tudo, é a história de uma peça de teatro e da recuperação mesma do teatro, como você falou. Para ter uma locação como essa, a gente precisava de um teatro desativado, que era o caso do TBC, um clássico da nossa cultura, que estava sendo recuperado na época. Não era um teatro com uma história de militância política, como o Arena ou o Oficina, 
mas era ali que estava toda a classe teatral, e, assim como hoje, a classe artística é muito atuante. Os artistas são sempre muito antenados com a necessidade da democracia, da liberdade de expressão, da liberdade de criação, da inclusão.

Aniki: Nesse momento, você poderia ter filmado em estúdio, mas preferiu se aproximar de um teatro real.

TA: Como sempre, eu prefiro colocar as pessoas em circunstância, porque os atores também ficam impregnados daquela coxia, daquele lugar. O tempo todo, eles comentavam: "nossa, eu li que tal peça aconteceu em tal momento", eles traziam as histórias do TBC. Para eles, que eram um jovem elenco, também tinha isso, estar no TBC, naquele teatro tão importante para a história da dramaturgia, do teatro, do espetáculo paulista, paulistano e brasileiro. Tão importante quanto eles estarem sendo dirigidos pelo Riccelli, que é um ator superexperiente. Aquele trecho de Os Pequenos Burgueses, que ele recita logo no início, quando se apossa do palco, é uma peça que ele fez no Oficina. Então, a locação traz uma vida para além do que está na tela, mas que contamina a interpretação dos atores.

Aniki: A escolha do Riccelli é muito marcante. Várias pessoas dizem que é o melhor papel dele no cinema. Como foi a escolha do Riccelli? Porque tem várias outras pessoas ligadas ao TBC, ao Arena, Oficina, que poderiam ter sido a sua escolha.

TA: Eu sempre dou muita sorte com ator. A escolha do Riccelli tem dois motivos. Um se chama Eles não usam Black-tie e outro Dois Córregos, no qual ele tem presença discreta, mas absolutamente marcante, com aquela voz internalizada. O Riccelli interpretou o filme todo com lágrimas nos olhos. Foi muito impressionante vê-lo tomar posse do Telmo e criar. Eu não vejo esse personagem com outro ator de jeito nenhum. Ele foi assumindo o Telmo de tal maneira que dois, três dias depois eu falava, "eu conheço esse cara". Riccelli interpretava os lapsos de memória do personagem com uma emoção tão grande que precisava parar para se recompor. Foi maravilhoso. Eu virei amiga dele de coração depois do filme. Numa das sessões do filme no Belas Artes, houve um debate após a projeção e a Dodora Arantes, que eu não conhecia, contou que o Riccelli e a Bruna ${ }^{7}$ iam frequentemente visitar os presos políticos para levar algum conforto. Riccelli nunca me contou isso, ele é muito discreto, mas deve ter sido a razão de ter entrado tanto na pele daquele personagem.

Aniki: A questão geracional está muito bem representada e caracterizada no filme com relação ao diretor, interpretado pelo Riccelli, e os outros atores de uma geração mais nova que desconfiam muito daquela história que está sendo contada.

\footnotetext{
${ }^{7}$ Bruna Lombardi, mulher de Carlos Alberto Ricelli.
} 
Sobretudo pelo fato de não se verem representados enquanto fala da periferia, ou uma mulher negra que diz: "mas não havia negros no movimento operário?" Isso acaba refletindo de uma maneira crítica ao movimento de esquerda daquele tempo, que era radical, expôs muitos jovens à tortura e à morte, mas no qual havia uma falta de diálogo com as massas, inclusive com os operários. Eu me lembro de ser parte da Liberdade e Luta e correr atrás de operário na fábrica para ver se eles adotavam a nossa causa, quando na verdade deveria ter sido o oposto. Gostaria de saber como foi conceber isso, que eu acho um ponto bastante válido levantado no filme.

TA: A defasagem entre as gerações está mais atual ainda neste momento. Uma das inspirações para isso foi, voltando ao Vinte/Dez, ter encontrado em Santo André uns meninos que faziam rap. Eles tinham uma música sobre o direito à terra, mas moravam num ambiente urbano. A explicação que um deles me deu é que tinha um avô que veio do Nordeste e um livro que ele tinha lido, chamado El plan agrario, numa edição bilíngue português e espanhol, mas publicado numa gráfica de Moscou. E eu falei: "mas como veio parar isso aqui na sua casa?" "Sei lá, tava aí, não sei”. Ou seja, foi aí que eu percebi que é uma geração que não tem a menor noção do que representa a reforma agrária, todo o contexto em que isso foi escrito, Lênin, a Revolução Russa, etc. Então eu percebi que a ditadura fez um corte cultural de memória e de referências. Outra coisa que ali no filme está ligeiramente problematizado, mas que hoje eu tenho muito mais consciência, até por outros trabalhos que eu fiz e precisei pesquisar, é essa dissociação daqueles grupos ligados à guerrilha do movimento operário, porque o movimento operário já tinha sido massacrado. Hoje, as pesquisas avançaram, descobriram histórias incríveis que a gente simplesmente não tem a memória de como foi, de como o movimento operário foi perseguido, dizimado, morto, e é por isso que, justamente, esses grupos de resistência estavam dissociados de qualquer organização sindical e política, porque essas já tinham sido combatidas e dizimadas. E há também o fato de que a narrativa histórica fica com quem conta a história. E quem mais contou a história foi a classe média - por razões de meios, principalmente. Outro dia, fui dar uma palestra na CUT e me perguntei: por que a gente não tem um museu de história operária nesse país? Cadê os filmes, cadê a história? A Comissão da Verdade trouxe, por exemplo, as violações de direitos dos índios, dos trabalhadores. A Volks pediu perdão pela colaboração que ela exerceu. Vários operários que estão ainda lutando por indenizações falam dos quartos onde eram trazidos os trabalhadores de que a empresa suspeitava de ligação sindical ou de luta. Lá mesmo eles eram torturados, a polícia ia lá. O relatório da Comissão da Verdade da prefeitura da cidade de São Paulo entregou agora um relatório onde investigou 45 violações de direitos com cumplicidade do poder municipal. O prefeito Fernando Haddad pediu desculpa em nome da prefeitura àquelas famílias, depois de ler o relatório e ficar chocado 
com o nível de cumplicidade. Então, essa dimensão eu não tinha na época da filmagem.

Aniki: Você tem todo um grupo de colaboradores no roteiro. Thiago Dottori, Willem Dias e Matias Mariani, que você já mencionou, contribuíram ou já tiveram experiência de tortura em si próprios ou familiares? Como foi a contribuição de cada um e como você dividiria a contribuição autoral final?

TA: Acho que todos somos autores. O Matias captou muito bem o que eu queria. Eu queria uma história que acontecesse num teatro e tivesse a ver com memória. Ele já era o produtor do Hoje, já estava envolvido nesse processo de busca. Seu primeiro argumento tinha uma sete ou dez páginas, e se não me engano tinha os flashbacks que insisti para que acontecessem no teatro, que fossem flashforwards, foi muito importante. Aí, o Thiago chegou e modificou um pouco o argumento. Soube depois que o pai dele sofreu tortura e ele tinha ido muito ao prédio do DOPS, ${ }^{8}$ onde hoje fica o Memorial da Resistência, e descobriu algumas coisas. Enfim, ele se colocou muito ali. Na filmagem, eu estava ali também buscando e foi muito importante o Matias ter gravado os depoimentos antes. Eu não conhecia nenhuma daquelas pessoas, a Amelinha, a Criméia, o Ivan, a Rita... ${ }^{9}$ Foi realmente decisivo ter visto esses depoimentos antes. Finalmente, o Willem Dias assina o roteiro, porque ele remontou aquele material que foi feito para uma série de quatro episódios e criou uma outra obra.

\footnotetext{
${ }^{8}$ DOPS é o Departamento de Ordem Política e Social de São Paulo onde ocorreram prisões e torturas nos anos 1960 e 70.

${ }^{9}$ Os sobreviventes de tortura entrevistados no filme são: Criméia Schmidt, Rita Sipahi, Ivan Seixas, Maria Amélia de Almeira Teles, Sergio Sister, Rose Nogueira e Elza Ferreira Lobo.
} 